\author{
Review Article \\ www.ijrap.net
}

\title{
LIFE STYLE DISEASE AND AYURVEDA: AN OVERVIEW AND PROSPECTIVE
}

\author{
Sreedevi S ${ }^{1}$, R.N Tripathy ${ }^{2 *}$ \\ ${ }^{1}$ PG Scholar, Department of Samhita Samskrita and Siddhanta, Government Ayurveda College, Thiruvananthapuram, \\ India \\ ${ }^{2}$ Professor, PG Department of Shalya Tantra, Amrita Viswa vidyapeetham, Amrita School of Ayurveda, Vallikkavu, \\ Kollam, Kerala, India
}

Received on: 08/01/17 Revised on: 20/01/17 Accepted on: 03/02/17

\begin{abstract}
*Corresponding author
E-mail: drrabi73@gmail.com
\end{abstract}

DOI: $10.7897 / 2277-4343.0816$

\begin{abstract}
Lifestyle diseases are the diseases primarily based on the daily habits of the people because of inappropriate relationship with the environment. According to Ayurveda, those diseases due to prajnaparadha (intellectual blemish) or asatmya indriyartha samyoga (unhealthy sensory perception) which results in disharmony in the body either as increase or decrease of Dosha are the lifestyle diseases. As per the WHO reports 38 million deaths occur globally per annum due to cardiovascular disease, diabetes, hyper tension, dyslipidemia, cancer etc. which put great pressure on the health care system as well as economic burden. At this juncture, it will be beneficial if the principles of Ayurveda and Yoga can be popularized among the common people where every individual can be the care taker of his own health. Ayurveda aims to maintain the health of a healthy person and to restore the health of the diseased. Rather than pacifying the symptoms, Ayurveda aims to achieve harmony in the functions of the body. Lifestyle corrections in accordance with one's Prakriti is the unique, simple and the best way that Ayurveda can contribute to tackle the great threat of life style diseases.
\end{abstract}

Keywords: Life style disease, Prakriti, Prajnaparadha, Asatmya indriyaartha samyoga.

\section{INTRODUCTION}

People even consider a "new generation" life style, as a socioeconomic status of today. The changing environments and lifestyles have remarkable impact on the health status of people. Lifestyle diseases are alarmingly high when the world became industrialized and life became more mechanical. According to a study report published in Times of India on 13th Aug, 2015, $25 \%$ of the Indians may die of lifestyle disease before they are $70^{1}$. Similarly, another study published in Indian Journal of Medical Research suggests that Lifestyle diseases are increasing in prevalence and need action ${ }^{2}$. It is high time to start action. For that, it is needed to know what are the lifestyle diseases, its causes, how to prevent them or how to get rid of them. Here a comprehensive approach is needed, when modern lifestyle creates diseases; the ancient science of life can reduce its impact. Ayurveda can give multidimensional care to manage and prevent the lifestyle diseases effectively.

Lifestyle diseases are the diseases primarily based on the daily habits of the people as a result of inappropriate relationship with the environment ${ }^{3}$. According to Ayurveda, those diseases; may be due to prajnaparadha (intellectual blemish) or asatmya indriyartha samyoga (unhealthy sensory perception) which results in disharmony in the body either as increase or decrease of Dosha are the lifestyle diseases ${ }^{4}$. The per capita income and living conditions of the people are favoring for a healthy generation now. But unfortunately, it is sad to observe a technologically and educationally rich generation with poor physical and mental ability. There is almost cent percent reduction in the communicable diseases due to advanced medical diagnosis, superior treatment and preventive measures. But the changes in lifestyle and dietary choices greatly increase the risk of non-communicable diseases or lifestyle diseases.
They are the silent killers and require long periods of excessive care to get rid of them. Hence, they are termed as chronic diseases by medical practitioners, which if not tackled as a national strategy, then a new generation of 'diseases of comfort' will become a major public health problem in the present and the next century.

No system can tackle all health concerns without the cooperation of the people. Most of the lifestyle diseases can be prevented by educating the public about healthy lifestyle. Ayurveda explains about the dynamics of life; what is beneficial for life and what is harmful for life; what happy life is and what unhappy life is; in physical, psychological, social and spiritual terms.

\section{Global Impact}

According to the WHO data, every year 38 million deaths occur worldwide due to cardiovascular disease, diabetes, hyper tension, dyslipidemia, cancer etc.; which put great pressure on the health care system as well as economic burden ${ }^{5}$. By the year 2005, India experienced the "highest loss in potentially productive years of life" globally and the leading cause was cardiovascular disease; mostly affecting people aged between 35-64 years. Sixteen million NCD deaths occur before the age of 70. Cardiovascular diseases account for most NCD deaths every year, (17.5 million) followed by cancers (8.2 million), respiratory diseases (4 million), and diabetes (1.5 million). Altogether these 4 groups of diseases account for $82 \%$ of all $\mathrm{NCD}$ deaths. If all forms of cancer can be eliminated, then the life expectancy of the population can be raised by an average of 3 years and in case of major cardiovascular disease, it can be up to 10 years. India is one of the nations with maximum number of lifestyle disorders in the near future as per the WHO data. 
As per the joint report of the World Health Organization and the World Economic Forum, India suffers an economic loss of 236.6 billion US dollars by the year 2015 due to lifestyle disorders and by 2030; this productivity loss is expected to be 17.9 million years' loss. This economy loss is about $1,000 \%$ greater than the corresponding loss in the United States ${ }^{6}$.

\section{Accountability}

The factors account for lifestyle diseases in the present scenario are mainly related to the job sector. The working environment in India has changed in recent decades giving priority to IT oriented services rather than physical activities. The ASSOCHAM (The Associated Chambers of Commerce and Industry of India) 2013 survey reports that nearly 85 percent of employees in private field are afflicted to life-style, chronic diseases and acute ailment compared to people with government job who are ranging below 8 percent $^{7}$. IT sector has been playing dominant role in Indian economy by its contribution to GDP (Gross domestic product) and employment generation capability, thus attracting majority of Indian youth. The study report by Preventive Healthcare and Corporate Female Workforce summarized that long hours of stressful, target oriented job leads 75 percent of working women to suffer from depression or anxiety ${ }^{3}$. Stressful working atmosphere along with unhealthy food habits, and several other 'addictions' are the early chariots that man chooses to his final destiny of rest- inpeace. Tobacco use, physical inactivity, alcohol abuse and unhealthy diets all increase the risk of $\mathrm{NCD}^{4}$. The prevalence of lifestyle diseases even among children are increasing at an alarming rate and the physical fitness of the children deteriorate drastically. While older generations celebrated the festive occasions by taking homely food, their grant children are being taken to huts and malls where artificial fast foods are available to be festive.

\section{Prevention}

In Ayurveda, the body, mind, food and environment are considered holistically to suggest a preventive and curative approach to health. The measures described in Ayurveda, in relation to prevention of diseases and induction of positive health must be taken in to consideration and it can be employed scientifically after updating it according to the present need in health care practices. The effort will help to prove the scientific validity of the ancient principles of health care and it may contribute many new amenities which will be fruitful in further planning of health care at both national and international level.

The motto of Ayurveda is "swasthasya swaasthya rakshanam, aaturasya vikaara prashamanam ${ }^{8}$ " i.e., Ayurveda aims to maintain the health of a healthy person and to restore the health of diseased. Rather than pacifying the symptoms, Ayurveda aims to achieve harmony in one's body functions. Health is mentioned as Swasthya- a balance in one's system biology. It is the state of equilibrium of the three principles of the body, namely Vata, Pitta and Kapha, along with a contented state of senses mind and soul ${ }^{9}$.

The four components of a person's daily life are Ahara (food), Achara (conduct), Vihara (behaviour) and Vichara (thoughts). When any of these components is, unhealthy there is imbalance in the Tridosha, which manifests as disease. As a response, whatever the measures be employed, are specified as Swastha vritta, which in short - avoidance of factors which cause imbalance and regular use of factors which maintain balance. Dinacharya is basically an ideal daily schedule for us to follow, which analyses the master cycles of nature and suggests optimal time for carrying out our daily routine. With the changing seasons of nature there will be corresponding effects on the human body. Ritucharya are activities specified for different season to protect human from diseases that occur due to change in season. For each season, there is a unique diet (ahara) and living (vihara) which keep the Dosha in a state of equilibrium and help man to cope with the stress and strain of changing seasons. Further, periodic bio-purification procedure (Panchakarma) as per the season helps to keep body in equilibrium and also as a preventive measure for probable incidence of specific diseases. Ayurveda instructs to get healthy progeny for a healthy future generation. Thus, Ayurveda even care for a healthy generation before the birth itself.

The existence and sustenance of human life are based on diet. Dietary consideration is an important component of every prescription in Ayurveda. Often dietary management itself is the treatment. Wholesome diet maintains the equilibrium of dhatu ( tissue), helps in promotion of health and prevention of diseases ${ }^{10}$. Ayurveda has dietary guidelines to choose appropriate food, mode of preparation, storage, manner of intake, eating atmosphere, hygiene, seasonal considerations and other etiquettes. Adequate emphasis has been given in the classics of Ayurveda regarding the right way of taking food ${ }^{11}$. It is advised to take food containing all tastes, according to one's Prakriti, in hygienic atmosphere, with optimum speed, when there is appetite, after offering prayer, with concentration and at the right time. One must consume according to digestive capacity (Agnibala), only after digestion of previous feed. The way food is served plays role in adding to the nutritional value. Food consumed in the right manner serves as nectar. The sequence is said as first madhura rasa (sweet taste) then amlalavana (sour- salty) then katu (pungent), tikta (bitter) and last kashaya rasa (astringent taste) must be taken ${ }^{12}$.

Ayurveda enlist certain food combinations which must be avoided at any coast, otherwise they will act like poison under the domain 'virudha' ${ }^{13}$ ( dietary incompatibility). For example, fish and milk together is considered as veerya virudha (incompatible in potency). Ayurveda even considers food as "mahabhaishajya", the superior medicine. It is told that, for those people practicing 'pathya ahara' (wholesome diet), there is no need to take any other medicine.

Every individual need health care based on their Prakriti (phenotype) or Vikruti (disease) in the line of his genomic profile. Even though, food is derived by individual from the environment, it's processing and use intimately depends on the integrity of internal bio-mechanism. Unless the bio-fire system (Agni) and inner bio-transport (Srotas) are in order, the process of nutrition may not accomplish. It is seen that Vata Prakriti will have Vishamagni ${ }^{14}$ (varied digestive fire) and are prone to Vata vikara (disease due to vitiated Vata). Similarly, Pitta Prakriti will have Tiksnagni (increased digestive fire) and Pitta vikara (disease due to vitiated Pitta) tendency. Kapha Prakriti will have Mandagni (decreased digestive fire) and are prone to Kapha vikara (disease due to vitiated Kapha). Sama Prakriti (constitution with balance of Vata, Pitta and Kapha) will have Samagni (balanced digestive fire) and they will have good resistance to diseases. By considering the "Prakriti" of the individual, physician can distinguish the diet that maintains the health.

Ayurveda proposes about medicinal dietary supplements in the context of Rasayana ${ }^{15}$. Most Rasayanas produce their nourishing and rejuvenating effect by acting as direct nutrients, by promoting the Agni Bala (digestive power), or by way of Srotoprasadana (clearing the channels), resulting in an improved 
nutritional status, further leading to an improved quality of Dhatu ( tissues).

\section{DISCUSSION}

In Ayurveda, diseases occurring due to lifestyle can be included under prajnaparadha (intellectual blemish) or asatmya indriyartha samyoga (unhealthy sensory perception); which result disharmony in the body either as increase or decrease of Dosha. The unhealthy lifestyle leads to angimandhya (diminished digestive fire), rasa vaigunya (vitiation of rasa dhatu), amasanchaya (accumulation of toxins), and further the srotorodha (obstruction of channels); depending up on that the pathology will be manifested.

The environment had a changed a lot. Those who are having enough bala (strength) and vyadhi kshamatwa (immunity) only can survive today. The preventive measures for diseases occurring to vitiation of Dosha mentioned in Ayurveda must be implemented wisely and effectively. The implementation plan must be started in the genetic level itself to get a healthy progeny. It is seen that most of the lifestyle diseases are running familial. If the parents are diabetic, children are prone to it. So as a precaution Ayurveda instructs that the marriage should happen between asanchari roga kula (non-disease running family) as well as a planned pregnancy by undergoing garbhadhana poorva shodhana (bio-purification before conceiving a child) and practicing the garbhini charya (pregnancy regimen).

A healthy atmosphere must be ensured at home, school as well as work sector. Sadvritta and sadachara (codes and conduct) must be learned from the home itself. It is better to practice a satwika diet. Ensure the cooking must have enough nutritional value, containing the shadrasa (six tastes). In today's circumstances, the apt instruction may be that 'don't over feed'. There should be provision to utilize Ayurveda to improve the health of school children. The importance of yoga, pranayama, vyayama (exercise), hitahara (wholesome diet) etc. for healthy life must be taught in the primary class itself. Stress reduction is very much important; as that it is clearly mentioned to lead ama sanchaya (accumulation of toxins). Prakriti based recruitment for job is a good option to practice, to appoint the right person for right work. For example, a Vata Prakrtiti person needs sooth and enthusiastic working atmosphere. If he is appointed for a security type job, it is not wise. Rather the stable nature of Kapha Prakriti makes him suitable there.

Ayurveda doctor can contribute a lot to make the community healthy. Modern medicine implements same type of health care all over the world. But it is highly significant that the geoclimatic factors have influence on the health status of the people. An Ayurveda doctor can educate people about a healthy regimen suitable to their 'desha' (region). The diet and regimen suitable to each Prakriti and can be instructed as well as provided as a chart. Health kit or periodic shodhana (bio-purification) kit can be supplied to the public based on the change in the environment.

The ancient Acharyas had shown the correct path to lead a healthy life. Even though, in today's world, it seems to be outdated effort must be taken to critically analyze the ancient thoughts in modern parlance and to update it for the current lifestyle and environment. For example, classically there are six seasons (shishira-vasantha-greeshma-varsha-sharat-hemantha) and accordingly six ritucharya (seasonal regimen) are mentioned. But everywhere people may not be experiencing all these seasons. Moreover, in indoor working atmosphere people are less likely getting exposed to change of seasons. If one can follow the daily regimen properly, seasonal variations may not hamper the body much. Acharya has told to do vyayama (exercise) according to the climatic conditions and strength of the person. Now according to the job, people need both physical and mental exercises. Walking is one of the healthiest forms of exercise and may be the one which can be practiced easily. Abhyanga (massage) is one of the regimens that Ayurveda instructs to do daily at least on the head, ear and foot which show its significance in maintaining health. Padabhyanga (foot massage) is good for eyes. This practice seeks special attention because now people are spending more time in front of television or computers, which cause eye strain. It is useful to do dhyana (meditation) before going to sleep. The time period entertained in sleep may vary according to age and occupation. Excess sleep and too little sleep are not healthy. Those who are not able to get good sleep in the night can go for a short nap during the day, in sitting posture itself as mentioned in the classics of Ayurveda. For people who may have to do night works, can do it on shift bases once in a week, and taking proper rest in the very next day after the night duty.

Ayurveda can do management of lifestyle diseases at three different stages. In the primordial management, high risk people are targeted and the needed diet-living can be instructed to balance their physiology. In the advanced stage of disease, care can be given to manage and to arrest the progress of the disease. Since almost all lifestyle diseases are primarily due to Santarpana (excess nourishment), in alpa dusti (slight Dosha vitiation), langhana (fasting) can be done. In madhyama dusti (moderate Doaha vitiation), langhana - pachana (fasting carminative) and in prabhoota dusti (excessive Dosha vitiation), shodhanaroopi langhana (bio - purification) can be done. In the terminal stage when the patient is vyadhi oushadha karshita (debilitated due to disease and medicine); Ayurveda can reduce the intensity of suffering up to an extent. There balya (strength promoting), agni deepana (enhancing the digestive power), vatanulomana roopi (normal uninterrupted movement of Vata) santarpana chikitsa (nourishing therapy) can be done.

Thus, the implementation time line can be divided in to three different stages i.e., to promote health, to prevent disorders, and to manage diseases. Individual, family and community must be educated about healthy food habits and other activities like vyayama, yoga, pranayama, and a positive life outlook by following dinacharya, ritucharya, sadvritta etc. Further an Ayurveda vaidya can recommend the medicinal plants in the chaya avastha (stage of Dosha accumulation) up to the poorvaroopa avastha (preliminary stage). Further in the acute as well as chronic phase of the disease, the satisfactory treatment can be provided along with the conventional and other complementary approaches based on the condition of the patient.

\section{CONCLUSION}

Lifestyle disorders constitute not only a major threat to the health of the people but also a major challenge for overall development of the nation. It is increasingly affecting the younger population at their active productive life. Thereby, it is not only increasing the number of productive life years lost, but also creating a big financial burden due to prolong health care cost. The current life style disorders can be tackled by practicing a healthy regimen. The principles of Ayurveda and Yoga can be popularized among the common people where every individual can be the care taker of his own health. Modern medicine recently invented that understanding the genetic makeup of an individual is the key towards personalized therapy, which the 
Ayurveda system of medicine practices from time eternal as the Prakriti based treatment. Lifestyle correction in accordance with one's Prakriti is the simplest and best way for health promotion, disease prevention and management of chronic diseases. It should be possible to combine the strength of Ayurveda with the advanced technologies of other allied science to provide quality traditional health care.

\section{REFERENCES}

1. http://timesofindia.indiatimes.com/india/25-of-Indians-maydie-of-lifestyle-diseases-before-they-are-70Study/articleshow/48460601.cms

2. Pappachan M J. Increasing prevalence of lifestyle diseases: high time for action. Indian J Med Res. 2011 Aug; 134(2): 143-145.

3. Sharma M, Majumdar PK. Occupational lifestyle diseases: An emerging issue. Indian J Occup Environ Med. 2009 Dec;13(3):109-12. doi: 10.4103/0019-5278.58912.

4. Murthy SKR. Ashtanga Hridaya. Reprint edition 2012; ed. Varanasi: Chaukhambha Orientalia; 2012.

5. http://www.who.int $/ \mathrm{nmh} /$ publications/ncd_report_chapter1.p df

6. Sabyasachi Senapati, Neetu Bharti, Amit Bhattacharya. Modern Lifestyle Diseases: Chronic Diseases, Awareness and Prevention. Int.J.Curr.Res.Aca.Rev.2015;3(7):215-223.

7. http://fspl.net.in/85-of-employees-in-private-sectorsafflicted-to-life-style-chronic-diseases-assocham-survey/

8. Cakrapanidatta. In: edited by Acharya Jadavji Trikamji. ed. Charaka Samhita. Reprint edition 2006; ed. Varanasi: Chaukhambha Orientalia; 2006.
9. Dalhana. In: edited by Acharya Jadavji Trikamji. ed. Susruta Samhita. Reprint edition 2014; ed. Varanasi: Chaukhambha Orientalia; 2014.

10. Sharma PV. Charaka Samhita. Reprint edition 2014; ed. Varanasi: Chaukhambha Orientalia; 2014.

11. Gupta Arvind Kumar, Charan Sharvan Singh, Goyal Anjali, Mishra Sangeeta S, Kedar Lal Meena. Ayurvedic dietetics: away to good health. International Journal Of Ayurvedic And Herbal Medicine 2:4 (2012) 703:716.

12. Dua Pradeep, Dua Pamila. Dietetics in Ayurveda - the forgotten science. Int.J.Res.Ayurveda.Pharm. 2011, 2(4) $1005-1010$.

13. Singh Satyapal. Principle and practice of nutrition and dietetics in Ayurveda. International Journal of Research in Pharmacy and Biosciences. Volume 2: Issue 7: August 2015;p1-7.

14. Mahajon Bidhan, Nath Rupashri, R. Remadevi. A scientific review on dietetics in Ayurveda according to Prakriti (innate constitution). IAMJ: Volume 2: Issue 6: NovemberDecember -2014 .

15. http://www.springer.com/cda/content/document/cda_downlo addocument/9781461496274-c1.pdf?SGWID $=0-0-4 \overline{5}-$ 1445758-p176340648.

\section{Cite this article as:}

Sreedevi S, R.N Tripathy. Life style disease and Ayurveda: An overview and prospective. Int. J. Res. Ayurveda Pharm. 2017;8(1):22-25 http://dx.doi.org/10.7897/2277-4343.0816

\section{Source of support: Nil, Conflict of interest: None Declared}

Disclaimer: IJRAP is solely owned by Moksha Publishing House - A non-profit publishing house, dedicated to publish quality research, while every effort has been taken to verify the accuracy of the content published in our Journal. IJRAP cannot accept any responsibility or liability for the site content and articles published. The views expressed in articles by our contributing authors are not necessarily those of IJRAP editor or editorial board members. 